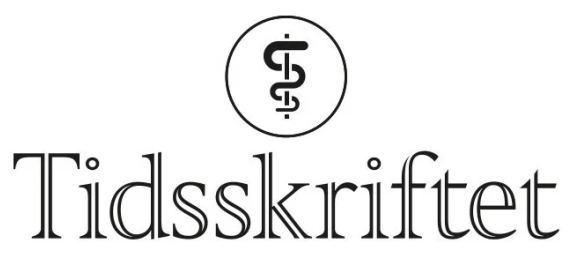

DEN NORSKE LEGEFORENING

\title{
Kvetiapin til folket?
}

KOMMENTAR

\section{PÅL GJERDEN}

pal.gjerden@sthf.no

Pål Gjerden er overlege ved Klinikk for psykisk helsevern og rusbehandling ved Sykehuset Telemark.

\section{LARS SLØRDAL}

Ingen av forfatterne har oppgitt noen interessekonflikter.

Helge Waal og medarbeidere går i rette med vår bekymring over den nær eksponensielle $ø$ kningen i bruk av det antipsykotiske midlet kvetiapin, og hevder at det «ikke er noe som tyder på at $\emptyset \mathrm{kt}$ bruk av kvetiapin skyldes $\emptyset \mathrm{kt}$ misbruk eller avhengighet av medikamentet $\mathrm{i}$ Norge» (11). Påstanden er problematisk på flere vis, men vi skal her nøye oss med å peke på følgende:

Vi har gjort en reseptregisterstudie av kvetiapinbruk i årene 2004-15 (므). I 2015 fikk 457 polikliniske pasienter minst to hvite resepter på kvetiapin med døgndoser over $400 \mathrm{mg}$, som er den definerte døgndosen. Dette utgjorde 5,4\% av alle som fikk forskrevet minst to resepter på kvetiapin. Til sammenligning fikk 351 pasienter $(4,1 \%)$ forskrevet samme doser på blå resept med henvisning til de to eneste godkjente refusjonspunktene, som er psykotisk eller affektiv psykisk lidelse. De resterende 90,5\% fikk forskrevet lavere doser. Vi mener det er nærliggende å anta at forskriving av høye doser egenfinansiert kvetiapin kan avspeile misbruk. Hva tror Hvaal et al. at disse 457 pasientene driver med?

\section{LITTERATUR}

1. Waal H, Vold JH, Skurtveit SO. Kvetiapinmisbruk - myte eller realitet? Tidsskr Nor Legeforen 2020; 140. doi: 10.4045/tidsskr.20.0059. [CrossRef]

2. Gjerden P, Bramness JG, Tvete IF et al. The antipsychotic agent quetiapine is increasingly not used as such: dispensed prescriptions in Norway 2004-2015. Eur J Clin Pharmacol 2017; 73: 1173-9. [PubMed] [CrossRef]

Publisert: 28. september 2020. Tidsskr Nor Legeforen. DOI: 10.4045/tidsskr.20.0704

(C) Tidsskrift for Den norske legeforening 2023. Lastet ned fra tidsskriftet.no 26. april 2023. 